\title{
EVALUASI PENGEMBANGAN EKONOMI NELAYAN PENERIMA PROGRAM BANTUAN LANGSUNG MASYARAKAT PENGEMBANGAN USAHA MINA PERDESAAN (BLM-PUMP) DI KELURAHAN TIDORE
}

\author{
Venancia Maengkom \\ Leonardus R. Rengkung \\ Agnes E. Loho
}

venancia_maengkom@yahoo.com

\section{ABSTRACT}

The aims of this researcxh are to evaluate and assess the effectiveness of Bantuan Langsung Masyarakat - Pengembangan Usaha Mina Perdesaan (BLM-PUMP) program, and to know the impact of the implementation of the program to the fishing communities' economic life in Tidore Village, Sub-district of East Tahuna. The village is one of the target area of the BLM - PUMP program. Research carried out for three months; with the number of respondents sample are 17 fishermen. Data were analyzed by descriptive qualitative and quantitative in tabulation form, percentage and scoring. The results showed that the BLM-PUMP program in Tidore Village accordance with the procedures and criteria set by the government. There are some deficiencies found in the implementation of the program: a) non-physical aid program forms is not used optimally; $b$ ) there is no capital turnover; c) supervisor does not properly function, assisting and training does not continue on to postdisbursement. BLM-PUMP program has produced output in the form of fishing infrastructure that is still used as a shared/KUB asset, and the Joint Business Group (KUB), but the function did not go well. BLM-PUMP program in the Village Tidore founded to be less effective, because the program objectives are not fully achieved. Distribution of BLM-PUMP only able to increase the income of fishermen, and foster entrepreneurial fishermen sufficiently, but are not able to improve the function of KUB institutional as a financial institution partners for fishermen. Nonetheless, the program provides economic impacts on fishing communities, which increase the income of fishermen and sufficiently reduce the dependence of fishermen on the capital providers/owners. (individual / institution).

Key words: fishing community, program effectiveness, Tahuna-Timur, Sangihe

\section{ABSTRAK}

Penelitian ini bertujuan untuk mengevaluasi dan mengkaji efektifitas Program Bantuan Langsung Masyarakat - Pengembangan Usaha Mina Perdesaan (BLM-PUMP), serta mengetahui dampak pelaksanaan Program BLMPUMP terhadap kehidupan ekonomi masyarakat nelayan di Kelurahan Tidore. Kelurahan Tidore Kecamatan Tahuna Timur merupakan salah satu daerah yang menjadi sasaran program BLM-PUMP. Penelitian dilaksanakan di selama 3 (tiga) bulan dengan jumlah responden 17 nelayan. Setelah melalui analisa data secara deskriptif kualitatif dan kuantitatif dalam bentuk tabulasi, persentase dan skoring, maka diperoleh hasil penelitian yaitu: Program BLM-PUMP di Kelurahan Tidore telah sesuai dengan prosedur dan kriteria yang ditetapkan pemerintah. Ada beberapa kekurangan yang ditemukan dalam pelaksanaan program, antara lain : a) bantuan program bentuk nonfisik tidak dipergunakan dengan optimal, b) tidak ada perputaran modal; c) tenaga pembimbing tidak berfungsi dengan baik, kegiatan pendampingan dan pelatihan tidak dilanjutkan terus ke pasca penyaluran dana. Program BLM-PUMP ini telah menghasilkan keluaran berupa infrastruktur penangkapan ikan yang masih digunakan dan Kelompok Usaha Bersama, namun tidak berfungsi dengan baik, sehingga didapati program BLM-PUMP di Kelurahan Tidore kurang efektif yang dikarenakan tujuan program tidak tercapai sepenuhnya, namun memberikan dampak terhadap perekonomian masyarakat nelayan, yaitu meningkatkan pendapatan nelayan dan cukup mengurangi ketergantungan nelayan terhadap para pemberi/pemilik modal. (individu/lembaga)

Kata kunci: nelayan tangkap, efektifitas program, Tahuna-Timur, Sangihe 


\section{PENDAHULUAN}

\section{Latar Belakang}

Kementerian Kelautan dan Perikanan Tahun 2010-2014 melaksanakan Program Pengembangan Usaha Mina Perdesaan (PUMP), dilatarbelakangi bahwa kondisi sosial ekonomi masyarakat pesisir pantai khususnya yang bermata pencaharian nelayan tradisional masih tergolong miskin.

Dahuri (2001) mengemukakan bahwa tingkat kesejahteraan para pelaku perikanan (nelayan) pada saat ini masih dibawah sektor-sektor lain, termasuk sektor pertanian agraris. Nelayan (khususnya nelayan buruh dan nelayan tradisional) merupakan kelompok masyarakat yang dapat digolongkan sebagai lapisan sosial yang paling miskin diantara kelompok masyarakat lain disektor pertanian

Sebagian besar masyarakat di Kelurahan Tidore Kecamatan Tahuna Timur menggantungkan hidupnya dari penghasilan laut (nelayan). Pada umumnya para nelayan tersebut cukup terampil menggunakan peralatan yang dimiliki dengan sarana penangkapan ikan yang ada (tradisional), namun keterampilan saja tidak cukup jika tanpa ditunjang peralatan yang memadai. Kondisi tersebut berakibat hasil penangkapan hanya sedikit atau dengan kata lain produktivitas nelayan rendah. Keterbatasan modal merupakan faktor utama penyebab rendahnya produktivitas nelayan. Hidup dengan keterbatasan biaya mengakibatkan fasilitas yang modern masih sulit dijangkau nelayan. Dipihak lain, para nelayan juga masih cenderung bersifat konsumtif sehingga peningkatan produktivitas usahanya tidak nyata.

Berdasarkan kondisi tersebut, maka Kelurahan Tidore merupakan salah satu daerah yang menjadi sasaran program BLM-PUMP. Pembentukan Kelompok Usaha Bersama (KUB) di Kelurahan Tidore sebagai lembaga yang ditunjuk untuk penyaluran dana BLM-PUMP, menjadi satu langkah baru dari masyarakat nelayan dalam mengembangkan kesejahteraan hidupnya. Nelayan yang tergabung dalam KUB akan menerima bantuan tersebut untuk digunakan sebagai modal usaha, dan KUB menjadi lembaga ekonomi yang harus mampu mengelola dana tersebut dengan sebaiknya. Oleh karena itu, perlu dilakukan penelitian yang mengkaji tentang pengembangan ekonomi nelayan penerima program Bantuan Langsung Masyarakat Pengembangan Usaha Mina Perdesaan (BLM-PUMP) di Kelurahan Tidore Kecamatan Tahuna Timur Kabupaten Sangihe.

\section{Perumusan Masalah}

1. Bagaimana pelaksanaan Program BLM-PUMP di Kelurahan Tidore?

2. Apakah Program BLM-PUMP di Kelurahan Tidore telah berjalan efektif?

3. Bagaimana dampak Program BLM-PUMP terhadap kehidupan ekonomi masyarakat nelayan di Kelurahan Tidore?

\section{Tujuan Penelitian}

1. Untuk mengevaluasi pelaksanaan Program BLM-PUMP di Kelurahan Tidore.

2. Untuk mengkaji efektifitas Program BLMPUMP di Kelurahan Tidore.

3. Untuk mengetahui dampak pelaksanaan Program BLM-PUMP terhadap kehidupan ekonomi masyarakat nelayan di Kelurahan Tidore.

\section{Manfaat Penelitian}

1. Sebagai rekomendasi kepada instansi terkait dalam hal ini pemerintah daerah Kabupaten Sangihe tentang pelaksanaan program Bantuan Langsung Masyarakat Pengembangan Usaha Mina Perdesaan (BLM-PUMP).

2. Sebagai bahan masukan bagi peneliti selanjutnya.

\section{METODOLOGI PENELITIAN}

\section{Tempat dan Waktu Penelitian}

Penelitian ini dilaksanakan di Kelurahan Tidore Kecamatan Tahuna Timur Kabupaten Sangihe Provinsi Sulawesi Utara. Jangka waktu penelitian yaitu selama 3 (tiga) bulan sejak bulan November 2014 sampai dengan bulan Februari 2015. 


\section{Jenis dan Sumber Data}

Data yang digunakan dalam penelitian ini adalah data primer dan data sekunder. Data primer diperoleh dari hasil wawancara langsung dan observasi. Data sekunder diperoleh dari studi pustaka menyangkut dokumen kegiatan Program Pengembangan Usaha Mina Perdesaan, kantor BPS dan data penunjang lainnya yang diperoleh melalui instansi-instansi terkait seperti Kantor Kelurahan Tidore dan Kecamatan Tahuna Timur.

\section{Teknik Pengambilan Contoh}

Lokasi penelitian dan responden dipilih secara sengaja (purposive sampling method). Kelurahan Tidore dipilih sebagai lokasi penelitian karena wilayah tersebut merupakan salah satu daerah pesisir yang menerima Program Bantuan Langsung Masyarakat Pengembangan Usaha Mina Perdesaan (BLM-PUMP) dan pada umumnya masyarakat yang ada berprofesi sebagai nelayan. Pengambilan contoh responden yaitu nelayan penerima Program Pengembangan Usaha Mina Perdesaan yang terdiri atas 2 (dua) Kelompok Usaha Bersama (KUB) dengan total keseluruhan responden yaitu 17 nelayan.

\section{Konsep Pengukuran Variabel}

Variabel - variabel yang diukur dalam penelitian ini yaitu meliputi:

1. Karakteristik Responden, meliputi :
a. Umur
b. Tingkat pendidikan
c. Jumlah Tanggungan

2. Evaluasi Program PUMP, yakni mengevaluasi pelaksanaan Program Pengembangan Usaha Mina Pedesaan dengan menggunakan evaluasi model CIPP

3. Efektifitas Program PUMP, diukur berdasarkan indikator terpenuhinya tujuan program PUMP Perikanan Tangkap, meliputi:

a.Pendapatan nelayan.

b.Kewirausahaan nelayan.

c. Kelembagaan ekonomi nelayan (KUB).
4. Dampak Program PUMP, yakni pengaruh yang muncul dari kegiatan program PUMP terhadap perekonomian nelayan.

5. Pendapatan, yaitu banyaknya penerimaan yang dihasilkan dari usaha menangkap ikan dikurangi biaya-biaya, dalam bentuk rupiah (Rp). Data pendapatan meliputi pendapatan sebelum dan sesudah program PUMP.

\section{Metode Analisis Data}

Data dianalisis secara deskriftif kualitatif untuk mendeskripsikan pelaksanaan program BLMPUMP dan kuantitatif dalam bentuk tabulasi, persentase, dan skoring.

Penentuan untuk menilai keefektifan program PUMP berdasarkan pada hasil pengukuran ketiga indikator tujuan program, dengan kategori efektif, kurang efektif dan tidak efektif. Program PUMP dikatakan efektif jika seluruh tujuan program tercapai, kurang efektif jika hanya dua tujuan program tercapai, dan tidak efektif jika seluruh tujuan program tidak tercapai.

Pengukuran indikator yang pertama (pendapatan) berdasarkan pada data perubahan dari pendapatan nelayan sebelum dan sesudah program, yang dilanjutkan dengan penentuan kategori. Kategori pada indikator pendapatan terdiri atas naik dan tidak naik. Kemudian dilakukan penentuan kategori untuk keseluruhan responden melalui tabulasi dan persentase.

Pengukuran indikator kewirausahaan dan kelembagaan dilakukan dengan metode deskriptif berupa pembobotan dari masing-masing pertanyaan, selanjutnya dibuat scoring dengan menggunakan skala tingkat (rating scale) menurut Skala Likert. Data yang diperoleh kemudian didistribusikan dalam kategori berbeda-beda.

Kategori pada indikator kewirausahaan terdiri atas 5 (lima), yaitu sangat tinggi, tinggi, cukup, kurang, dan sangat kurang, sedangkan kategori pada indikator kelembagaan ada 3 (tiga) yaitu terdiri atas berfungsi, kurang fungsi, dan tidak berfungsi. 


\section{HASIL DAN PEMBAHASAN}

\section{Karakteristik Responden Nelayan}

\section{Umur}

Suharjo dan Patong (1984) dalam Firdaus (2014) mengelompokkan umur bersadarkan kelompok produktif yaitu umur antara 15 - 54 tahun dan kelompok non produktif yaitu umur diatas 55 tahun. Kemampuan kerja seseorang dipengaruhi oleh kemampuan fisik dan cara berfikir berdasarkan umur, dimana kemampuan kerja akan bertambah dan mencapai maksimal pada umur tertentu dan akan mengalami kemunduran / penurunan kemampuan di umur tertentu pula.

Jumlah nelayan di Kelurahan Tidore menurut golongan umur dapat dilihat pada Tabel 1 .

Tabel 1. Jumlah Nelayan menurut Umur

\begin{tabular}{ccc}
\hline \multirow{2}{*}{$\begin{array}{c}\text { Umur } \\
\text { (tahun) }\end{array}$} & \multicolumn{2}{c}{ nelayan } \\
\cline { 2 - 3 } & Jumlah & $\begin{array}{c}\text { Persentase } \\
\text { (Orang) }\end{array}$ \\
\hline $23-40$ & 5 & 29 \\
$41-55$ & 11 & 65 \\
$>55$ & 1 & 6 \\
\hline Jumlah & 17 & 100 \\
\hline
\end{tabular}

Sumber : Diolah dari data primer, 2015

Pada Tabel 1, menunjukkan bahwa kisaran umur responden nelayan di Kelurahan Tidore yaitu 23 - 55 tahun. Sebagian besar responden yakni sebesar 65 persen berada pada kelompok umur 41 55 tahun, diikuti kelompok umur 23 - 40 tahun sebesar 29 persen dan sebesar 6 (enam) persen berada pada kelompok umur lebih dari 55 tahun. Uraian tersebut menunjukkan bahwa responden nelayan berada pada kisaran kategori umur yang produktif.

\section{Tingkat Pendidikan}

Komoditas perikanan merupakan komoditas yang cepat busuk yang dapat mempengaruhi harga/nilai jual dari komoditas tersebut. Seorang nelayan dengan tingkat pendidikan yang lebih tinggi akan lebih tanggap dalam menata usaha tangka- pannya, yang dampaknya akan terlihat pada tingkat pendapatan yang diterimanya.

Berikut jumlah nelayan di Kelurahan Tidore menurut tingkat pendidikan yang terangkum pada Tabel 2.

Tabel 2. Jumlah Nelayan menurut Tingkat Pendidikan

\begin{tabular}{ccc}
\hline \multirow{2}{*}{$\begin{array}{c}\text { Tingkat } \\
\text { Pendidikan }\end{array}$} & \multicolumn{2}{c}{ nelayan } \\
\cline { 2 - 3 } & $\begin{array}{c}\text { Jumlah } \\
\text { (Orang) }\end{array}$ & $\begin{array}{c}\text { Persentase } \\
(\%)\end{array}$ \\
\hline SD & 5 & 29 \\
SMP & 5 & 29 \\
SMA & 7 & 42 \\
\hline Jumlah & 20 & 100 \\
\hline
\end{tabular}

Sumber : Diolah dari data primer, 2015

Hasil penelitian yang terangkum pada Tabel 2 mendapati bahwa pendidikan mayoritas responden nelayan di Kelurahan Tidore termasuk dalam kategori cukup tinggi. Hal ini terlihat pada tingkat pendidikan SMA yang memiliki nilai persentase terbesar yakni 42 persen.

\section{Jumlah Tanggungan}

Badan Pusat Statistik (BPS) melakukan pengelompokan jumlah tanggungan keluarga pada beberapa kategori yaitu tanggungan kecil dengan jumlah anggota keluarga $1-3$ orang, sedang dengan jumlah tanggungan keluarga $4-6$ orang dan besar dengan jumlah tanggungan keluarga lebih dari 6 orang.

Jumlah tanggungan responden nelayan di $\mathrm{Ke}$ lurahan Tidore dapat dilihat pada Tabel 3.

Tabel 3. Jumlah Nelayan menurut Tanggungan

\begin{tabular}{ccc}
\hline \multirow{2}{*}{$\begin{array}{c}\text { Jumlah } \\
\text { Tanggungan }\end{array}$} & \multicolumn{2}{c}{ nelayan } \\
\cline { 2 - 3 } & $\begin{array}{c}\text { Jumlah } \\
\text { (Orang) }\end{array}$ & $\begin{array}{c}\text { Persentase } \\
(\%)\end{array}$ \\
\hline $1-3$ & 7 & 41 \\
$4-6$ & 9 & 53 \\
$>6$ & 1 & 6 \\
\hline Jumlah & 20 & 100 \\
\hline
\end{tabular}

Sumber : Diolah dari data primer, 2015 
Tabel 3 menunjukkan bahwa sebagian besar responden nelayan mempunyai jumlah tanggungan 4 - 6 orang, yakni sebesar 53 persen dari total responden. Diikuti jumlah tanggungan $1-3$ orang dan lebih dari 6 (enam) orang masing-masing sebesar 41 persen dan 6 (enam) persen. Dapat disimpulkan bahwa jumlah tanggungan nelayan di Kelurahan Tidore termasuk dalam kategori sedang, dengan kata lain kesadaran nelayan tentang keluarga berencana yang dicanangkan pemerintah cukup tinggi.

\section{Evaluasi Program Bantuan Langsung Masyara- kat Pengembangan Usaha Mina Pedesaan (BLM-PUMP)}

Evaluasi program Bantuan Langsung Masyarakat Pengembangan Usaha Mina Pedesaan (BLMPUMP) dilakukan dengan menggunakan model CIPP.

\section{Konteks (Context)}

Program Bantuan Langsung Masyarakat Pengembangan Usaha Mina Pedesaan (BLMPUMP) merupakan pendekatan pengembangan usaha nelayan untuk meningkatkan pendapatan dan kesejahteraan nelayan (Kementerian Kelautan dan Perikanan 2010). Sesuai dengan misi kementerian kelautan dan perikanan Tahun 2010-2014, yaitu "Mensejahterakan Masyarakat kelautan dan perikanan".

Kelurahan Tidore merupakan salah satu daerah pesisir yang menjadi sasaran dari program PUMP, karena sebagian besar masyarakat bergantung pada usaha penangkapan ikan atau berprofesi sebagai nelayan. Selain alasan tersebut, sebagian besar masyarakat nelayan belum memenuhi standar kesejahteraan. Pendapatan yang diperoleh dari usaha melaut tidak atau belum mencukupi pemenuhan kebutuhan primer dan sekunder. Hal ini ditunjukkan sebagian besar nelayan belum memiliki tempat tinggal yang tetap, tingkat pendidikannya belum mencapai standar dan kurangnya sarana prasarana yang menunjang untuk pekerjaan.

Pelaksanaan program PUMP perikanan tangkap di Kelurahan Tidore, diharapkan akan memberi pe- rubahan bagi perekonomian masyarakat nelayan sesuai dengan apa yang menjadi tujuan program PUMP yaitu meningkatkan pendapatan nelayan, menumbuhkan kewirausahaan nelayan, dan meningkatkan fungsi kelembagaan ekonomi nelayan.

\section{Masukan (input).}

Program BLM-PUMP menyedot $87 \%$ anggaran Bantuan Langsung Masyarakat (BLM) PNPM Mandiri KP Tahun 2012 yang besarnya hingga 783,85 milyar sebagaimana data yang dilansir Sekretariat Jenderal KKP. Pemerintah memberikan bantuan melalui BLM-PUMP dalam bentuk fisik dan non fisik.

Bantuan dalam bentuk fisik yaitu dana BLM PUMP berupa uang sebesar Rp. 100.000.000 telah diberikan kepada setiap Kelompok Usaha Bersama (KUB) yang disesuaikan dengan rekening masing-masing KUB pada bulan November 2014.

Bantuan non fisik dari program BLM-PUMP antara lain berupa :

a. Sosialisasi program yang diberikan oleh tim teknis terdiri atas kepala dinas, kepala seksi bidang perikanan tangkap dan pendamping. Kegiatan sosialisasi telah dilakukan sebanyak 2-6 kali kepada 2 (dua) KUB dengan waktu yang berbeda, namun tidak dihadiri oleh semua anggota KUB tapi diwakilkan oleh ketua kelompok.

b.Pengelola KUB telah sesuai dengan syarat ketentuan, yaitu minimal pendidikan lulusan SMA.

c.SDM Penyuluh Pendampingan disediakan sesuai dengan syarat ketentuan minimal pendidikan lulusan SMA dan telah mengikuti pelatihan pendampingan.

d.Kelengkapan administrasi KUB tidak dipergunakan secara optimal., manajemen pengurus KUB ketua kelompok, bendahara dan sekretaris tidak berjalan sesuai dengan fungsinya.

e.Pelatihan diadakan oleh pemerintah untuk menambah kualitas SDM pengelola KUB dan penyuluh pendamping, namun tidak semua pengelola KUB mengikuti pelatihan.

f. Penyusunan Rencana Usaha Bersama (RUB). Kegiatan pengelolaan dana tidak mengikuti RUB. 


\section{Proses (Process)}

Pelaksanaan program BLM-PUMP di Kelurahan Tidore dimulai dari penentuan lokasi atau tempat dilaksanakannya program, dan telah dilaksanakan sesuai kriteria dan prosedur. Kelurahan Tidore merupakan salah satu daerah yang termasuk lokasi minapolitan berbasis perikanan tangkap yang telah membentuk Kelompok Usaha Bersama (KUB), yaitu KUB Senggihiang dan Tenggiri yang terdaftar dan masuk dalam database di Dinas Kabupaten/Kota, Provinsi dan Direktorat PUPI.

Penyaluran dana BLM-PUMP dalam bentuk uang tunai telah didistribusikan kepada nelayan yang layak atau sesuai kriteria, yaitu merupakan pengurus atau anggota KUB Senggihiang dan Tenggiri. Dimana proses pemilihannya sesuai dengan rencana usaha bersama (RUB) yaitu nelayan kecil yang memiliki kartu nelayan.

Cara dan prosedur penyaluran, serta pengembalian dana BLM-PUMP tersebut diatur dalam rancangan usaha bersama (RUB) yang disusun dan disepakati oleh seluruh anggota KUB, dengan maksud agar dana tersebut bisa dikelola sebagai modal untuk usaha bersama selanjutnya (perputaran modal). Berkaitan dengan hal tersebut, kelembagaan KUB dituntut untuk memiliki kemampuan mengelola dana BLM-PUMP dengan sebaiknya.

Proses penyaluran dana telah dilakukan sesuai dengan RUB masing-masing KUB, yaitu secara bertahap sebanyak 2 (dua) kali, namun peruntukkan dana berbeda pada tiap tahap pencairan. Pada KUB Sengghigilang, penyaluran tahap pertama berjumlah Rp 80.000.000,- diperuntukkan kebutuhan pembuatan bagan/rumpon pembuatan perahu, pengadaan mesin dan biaya operasional, tahap kedua sejumlah Rp 20.000.000,- untuk kebutuhan biaya konsumsi, pemeliharaan dan pembelian jala, tali. Sedangkan KUB Tenggiri, tahap pertama penyaluran berjumlah Rp 50.000.000,- diperuntukkan pembuatan bagan/rumpon dan pengadaan mesin dan tahap kedua sejumlah Rp 50.000.000,- untuk biaya perbaikan perahu, pembelian tali, jala, operasional, dan sewa.

Keberhasilan proses penyaluran dana BLMPUMP pada kedua KUB tersebut, sayangnya tidak diikuti oleh proses pengembalian dananya. Hasil observasi mendapati bahwa nelayan penerima dana
BLM-PUMP tidak satupun melakukan pengembalian, akibatnya tidak ada perputaran dana yang bisa digunakan untuk modal usaha selanjutnya.

Kondisi tersebut disebabkan antara lain kurangnya kemampuan pengelola KUB dalam mengelola dana, yang diakibatkan dari kurangnya bimbingan dan pelatihan yang diberikan. Tenaga pembimbing tidak berfungsi dengan baik, informasi mengenai pengelolaan dana hanya disosialisasikan, namun tidak intensif dilanjutkan terus pada proses pasca penyaluran dana. Padahal kegiatan pasca penyaluran dana ini merupakan tolok ukur untuk menilai apakah tujuan program BLM-PUMP telah tercapai.

Kurangnya pembekalan melalui kegiatan bimbingan dan pelatihan pasca penyaluran dana berakibat pengelola KUB tidak memiliki pengetahuan, sehingga tidak memiliki kemampuan untuk mengelola dana tersebut. Selain itu, kurangnya informasi menyeluruh tentang program BLM-PUMP menimbulkan kekeliruan pemikiran atau pengertian nelayan penerima. Sebagian besar nelayan penerima menganggap dana tersebut merupakan bantuan yang habis digunakan untuk keperluan usahanya, tanpa harus dikembalikan. Kurangnya informasi tersebut juga disebabkan kurangnya kepedulian nelayan untuk hadir dalam kegiatan sosialisasi, dan pertemuan-pertemuan. Berdasarkan hasil wawancara dengan pengelola KUB terutama ketua kelompok, diperoleh penjelasan bahwa dari awal setiap ada kegiatan sosialisasi, pertemuan, pelatihan/bimbingan dari dinas, hanya ketua yang berpatisipasi dalam kegiatan tersebut.

\section{Produk/keluaran (Product)}

a.Dana BLM-PUMP yang telah telah berhasil disalurkan kepada 2 (dua) KUB, yaitu KUB Sengghigiang dan KUB Tenggiri. Dana tersebut juga telah disalurkan ke nelayan secara merata. Dana BLM PUMP tersebut dimanfaatkan sebagai modal usaha anggota KUB sesuai dengan RUB yang digunakan untuk infrastruktur penangkapan ikan sebagai aset bersama/KUB, antara lain pembuatan bagan/rumpon, pengadaan alat tangkap, mesin, perahu, perbaikan dan kelengkapan dalam kegiatan penangkapan ikan, dan biaya operasional, sewa, konsumsi. 
b.Kelompok Usaha Bersama yang telah terbentuk difasilitasi untuk menguatkan kapasitas dan kemampuan pengelola KUB berupa pendampingan dan pelatihan, namun kegiatan tersebut hanya berlangsung pada saat awal proses pembentukan KUB sampai pada penyaluran dana. Kegiatan bimbingan dan pelatihan tidak dilanjutkan terus ke proses pasca penyaluran dana, terutama mengenai pembekalan pengetahuan pengelola KUB dalam mengelola dana. Kelompok Usaha Bersama (KUB) sebagai lembaga ekonomi masyarakat nelayan tidak mampu berfungsi sebagaimana yang diharapkan.

\section{Efektifitas Program BLM-PUMP}

Penentuan efektifitas program BLM-PUMP ditentukan berdasarkan tercapainya ketiga tujuan program BLM-PUMP. Tujuan program BLMPUMP yaitu sebagai berikut :

1. Meningkatkan pendapatan nelayan melaui kegiatan pengembangan usaha nelayan skala kecil di perdesaan.

2. Menumbuhkembangkan kewirausahaan nelayan.

3. Meningkatkan fungsi kelembagaan ekonomi nelayan menjadi mitra lembaga keuangan dalam rangka akses permodalan

Hasil penelitian mendapati bahwa program BLM-PUMP ternyata kurang efektif, hal ini dikarenakan tujuan program tidak kesemuanya tercapai. Dari 3 (tiga) tujuan program, hanya satu tujuan yang nyata telah tercapai yaitu meningkatkan pendapatan nelayan. Tujuan program yang kedua yakni menumbuhkembangkan kewirausahaan nelayan, dapat disimpulkan cukup tercapai, walaupun perubahannya tidak terlalu signifikan. Tujuan program yang ketiga yakni meningkatkan fungsi kelembagan KUB sebagai mitra lembaga keuangan, tidak tercapai.

Berikut hasil penilaian dari ketiga indikator keefektifan program BLM-PUMP, yaitu :

\section{Pendapatan}

Usaha perikanan tangkap di Kelurahan Tidore merupakan sumber pendapatan utama bagi nelayan, disamping sumber pendapatan lain seperti buruh bangunan, tukang ojek ataupun berdagang. Usaha perikanan tangkap ini di dominasi nelayan tradisional, yang dicirikan oleh teknologi sederhana, sangat dipengaruhi oleh musim dan hasil produksi/tangkapan terbatas untuk konsumsi lokal.

Penyaluran dana BLM-PUMP telah digunakan sepenuhnya untuk keperluan pembelian mesin, perbaikan perahu, dan pembuatan bagan, sehingga mengakibatkan produktivitas nelayan menjadi lebih besar, sebab nelayan telah memiliki sarana yang dibutuhkan agar mampu memperluas jangkauan area tangkapan. Peningkatan produktivitas nelayan berakibat pendapatan nelayan juga turut meningkat.

Produksi atau jumlah tangkapan nelayan bervariasi jenis dan jumlah ikannya. Jenis ikan yang sebagian besar dihasilkan yaitu antara lain tude, malalugis, cakalang dan deho. Harga jual ikan yang berlaku pada saat data diambil yaitu tude $\mathrm{Rp}$ 360.000 per keranjang, malalugis Rp 250.000 per keranjang, cakalang Rp 150.000 per keranjang, dan deho Rp 230.000 per keranjang. Jumlah ikan per keranjang untuk jenis ikan tude 360 ekor, malalugis 160 ekor, cakalang 6 ekor, dan deho 125 ekor.

Biaya operasional pada penelitian ini yaitu terdiri atas biaya tansportasi, konsumsi dan biaya jaga tempat bagan/rumpon. Biaya transportasi yang dimaksud ialah biaya bahan bakar yang digunakan yaitu bensin dan solar. Harga beli bensin Rp 5000 per liter dan solar Rp 4000 per liter. Biaya untuk menjaga bagan/rumpon berbeda untuk kedua KUB, yaitu pada KUB Senggihiang sebesar Rp 700.000 per kelompok dan pada KUB Tenggiri sebesar Rp 1.000.000 per kelompok.

Berdasarkan hasil penelitian diperoleh bahwa jumlah tangkapan nelayan sesudah program PUMP mengalami peningkatan yang mengakibatkan pendapatan nelayan juga meningkat, seperti yang terlihat pada Tabel 4.

Berdasarkan Tabel 4, terlihat bahwa rata-rata pendapatan nelayan penerima BLM-PUMP Perikanan Tangkap sebelum program PUMP yaitu sebesar Rp 83.107 dan sesudah program sebesar Rp 123.821, dengan persentase kenaikan yaitu sebesar 49\%, yang tersebar kepada dua KUB. Rata-rata pendapatan pada KUB Senggihiang sebelum program yaitu sebesar Rp 80.714, dan sesudah pro- 
gram PUMP sebesar Rp 85.500, dengan persentase kenaikan sebesar 39\%. Pada KUB Tenggiri, ratarata pendapatan sebelum program PUMP yaitu sebesar Rp 112.143 dan sesudah sebesar Rp 135.500, maka persentase kenaikan pendapatan sebesar $58 \%$.

Tabel 4. Pendapatan Nelayan Sebelum dan Sesudah Program PUMP

\begin{tabular}{cccc}
\hline \multirow{2}{*}{ Nama KUB } & \multicolumn{2}{c}{ Pendapatan (Rp) } & Persentase \\
\cline { 2 - 3 } & Sebelum & Sesudah & $\begin{array}{c}\text { Kenaikan } \\
(\%)\end{array}$ \\
\hline Senggihiang & 80.714 & 85.500 & 39 \\
Tenggiri & 112.143 & 135.500 & 58 \\
\hline Rata-rata & 83.107 & 123.821 & 49 \\
\hline
\end{tabular}

Sumber : Diolah dari data primer, 2015

Secara keseluruhan, sebagian besar nelayan penerima program BLM-PUMP berpendapat bahwa program BLM-PUMP sangat membantu perekonomian keluarga nelayan, karena pendapatan nelayan mengalami kenaikan. Hal tersebut terlihat pada Tabel 5.

Berdasarkan Tabel 5 diketahui bahwa nelayan yang termasuk kategori pendapatan naik, yaitu sebesar 76,47 persen, sedangkan yang termasuk kategori tidak naik (tetap) sebesar 23,53 persen. Hal ini menunjukkan bahwa pendapatan nelayan mengalami kenaikan sesudah program BLM-PUMP dilaksanakan, sehingga bisa disimpulkan bahwa program BLM-PUMP di Kelurahan Tidore efektif meningkatkan pendapatan nelayan.

Tabel 5. Penilaian Indikator Pendapatan Nelayan

\begin{tabular}{ccc} 
Kategori & $\begin{array}{c}\text { Jumlah Re- } \\
\text { sponden } \\
\text { (Orang) }\end{array}$ & $\begin{array}{c}\text { Persentase } \\
(\%)\end{array}$ \\
\hline Naik & 13 & 76,47 \\
Tidak Naik & 4 & 23,53 \\
\hline Total & 17 & 100 \\
\hline
\end{tabular}

Sumber : Diolah dari data primer, 2015

\section{Kewirausahaan}

Jiwa kewirausahaan akan sangat menentukan keberhasilan dalam kegiatan usaha baik dari sejak perencanaan, pelaksanaan, maupun evaluasi ter- hadap usaha yang dilakukannya. Seorang nelayan harus memiliki profil kewirausahaan dengan segala ciri-cirinya, karena nelayan juga bisa disebut sebagai seorang pengusaha yang memimpin usahanya dalam menangkap ikan. Tidak hanya itu, nelayan sebagai bagian dari KUB dalam hal ini sebagai pengelola KUB dituntut untuk bisa memiliki kepemimpinan, tetapi yang lebih penting adalah sikap mental wirausaha, manajemen dan keterampilan.

Pengukuran indikator kewirausahaan dilakukan dengan cara pemberian skor pada setiap jawaban atas pertanyaan. Alternatif jawaban terdiri dari : selalu (skor 3), kadang-kadang (skor 2), dan tidak pernah (skor 1). Data kemudian didistribusikan dalam kategori sangat tinggi, tinggi, cukup, kurang tinggi, dan sangat kurang.

Penilaian kewirausahaan nelayan, baik sebagai individu maupun sebagai pengelola KUB dapat dilihat pada Tabel 6 .

Tabel 6 memperlihatkan bahwa indikator kewirausahaan yang menghasilkan persentase terbesar yaitu responden dengan kategori cukup, yaitu sebesar 70,59 persen. Diikuti oleh responden kategori kurang tinggi, yaitu sebesar 17,65 persen, dan kategori tinggi yaitu sebesar 1,76 persen. Hasil penelitian juga menunjukkan bahwa tidak ada satupun responden yang memiliki kewirausahaan pada kategori sangat tinggi dan sangat kurang.

Tabel 6. Penilaian Indikator Kewirausahaan

\begin{tabular}{ccc}
\hline Kategori & $\begin{array}{c}\text { Jumlah Re- } \\
\text { sponden } \\
\text { (Orang) }\end{array}$ & $\begin{array}{c}\text { Persentase } \\
(\%)\end{array}$ \\
\hline Sangat Tinggi & 0 & 0 \\
Tinggi & 2 & 1,76 \\
Cukup & 12 & 70,59 \\
Kurang & 3 & 17,65 \\
Sangat Kurang & 0 & 0 \\
\hline Total & 17 & 100 \\
\hline
\end{tabular}

Sumber: Diolah dari data primer, 2015

Hal tersebut menandakan bahwa untuk indikator kewirausahaan sebagian besar nelayan di Kelurahan Tidore termasuk pada kategori cukup, sehingga bisa dikatakan kewirausahaan nelayan mengalami perubahan yang tidak terlalu signifikan. 
Dengan demikian berarti tujuan program PUMP yaitu menumbuhkembangkan kewirausahaan nelayan cukup tercapai.

\section{Kelembagaan KUB}

Keberadaan kelembagaan KUB dibentuk setelah disosialisasikan program PUMP yang mensyaratkan sasaran penyaluran dana BLM-PUMP yaitu nelayan-nelayan yang tergabung dalam KUB. Pembentukkan KUB diharapkan mampu menyalurkan dan mengolah dana sebagai modal usaha nelayan, dengan demikian KUB merupakan mitra lembaga keuangan bagi nelayan.

Pengukuran indikator kelembagaan dilakukan dengan cara yang sama dengan pengukuran indikator kewirausahaan yaitu melalui pemberian skor pada setiap jawaban atas pertanyaan. Alternatif jawaban terdiri dari: ya/selalu (skor 3), raguragu/jarang (skor 2), dan tidak/tidak pernah (skor 1). Data kemudian didistribusikan dalam kategori kelembagaan berfungsi, kurang berfungsi, dan tidak berfungsi.

Penilaian kelembagaan Kelompok Usaha Bersama (KUB) dapat dilihat pada Tabel 7.

Tabel 7, menunjukkan bahwa responden yang menilai kelembagaan KUB tidak berfungsi yaitu sebesar 35,29 persen, sedangkan kurang berfungsi yaitu sebesar 64,71 persen. Tidak ada satupun responden yang menilai bahwa kelembagaan KUB berfungsi.

Tabel 7. Penilaian Indikator Kelembagaan KUB

\begin{tabular}{ccc}
\hline Kategori & $\begin{array}{c}\text { Jumlah Re- } \\
\text { sponden } \\
\text { (Orang) }\end{array}$ & $\begin{array}{c}\text { Persentase } \\
(\%)\end{array}$ \\
\hline Berfungsi & 0 & 0 \\
Kurang berfungsi & 11 & 64,71 \\
Tidak berfungsi & 6 & 35,29 \\
\hline Total & 17 & 100 \\
\hline
\end{tabular}

Sumber : Diolah dari data primer, 2015

Hal tersebut menandakan bahwa kelembagaan KUB di kelurahan Tidore kurang berfungsi, atau fungsi kelembagaan KUB tidak berjalan efektif. Dengan demikian berarti tujuan program PUMP yaitu meningkatkan fungsi kelembagaan, tidak tercapai.

\section{Dampak Program PUMP terhadap Perekonomian Masyarakat Nelayan di Kelurahan Tidore}

Kemiskinan dan rendahnya tingkat kesejahteraan merupakan sebuah realitas umum yang terjadi di kalangan nelayan. Tak terkecuali perekonomian masyarakat nelayan di Kelurahan Tidore yang secara umum tidak jauh berbeda dengan keadaan perekonomian masyarakat nelayan di daerah-daerah lainnya, dimana tingkat kesejahteraan masyarakatnya masih jauh dari standar.

Kemiskinan yang begitu melekat pada nelayan, khususnya nelayan tangkap dan buruh nelayan telah direspon oleh pemerintah dengan berbagai program. Berbagai program penanggulangan kemiskinan yang ditujukan kepada nelayan telah diterapkan, seperti Program Pemberdayaan Masyarakat Pesisir (PEMP), Program Pengembangan Usaha Perikanan Tangkap Skala Kecil (PUPTSK), dan Program Bantuan Langsung Masyarakat Pengembangan Usaha Mina Perdesaan (BLM-PUMP). Program BLMPUMP merupakan bagian dari Program Nasional Pemberdayaan Masyarakat Mandiri yang memberikan stimulus modal usaha perikanan tangkap berdasarkan potensi sumberdaya perikanan. Tujuan program adalah memperbaiki sumber-sumber pendapatan yang diharapkan dapat meningkatkan kesejahteraan nelayan skala kecil yang tergabung dalam Kelompok Usaha Bersama (KUB). Program BLMPUMP merupakan program kebijakan penanggulangan kemiskinan nelayan berbasis aset dan jalur kelembagaan.

Penanggulangan kemiskinan dalam program BLM-PUMP dilakukan melalui pemberian modal usaha yang digunakan untuk pembelian infrastruktur alat tangkap yang diharapkan dapat menjadi aset produktif bagi nelayan dalam melaksanakan aktivitas ekonomi yang dapat meningkatkan produktifitas sekaligus nilai manfaat dari produktifitas sebagai konsekwensi akumulasi dari kepemilikan aset. Program BLM-PUMP di Kelurahan Tidore dimulai dari bulan November 2014, dimana penggunaan dananya yaitu untuk 
kebutuhan infrastruktur alat tangkap berdampak kepada peningkatan produktifitas nelayan, yang juga berdampak terhadap pendapatan petani. Hasil penelitian menunjukkan bahwa pendapatan nelayan mengalami peningkatan sejak program BLMPUMP ini dilaksanakan.

Unsur utama dalam melihat kesejahteraan maupun kemiskinan adalah Pendapatan. Pendapatan merupakan arus mengalirnya uang dalam sebuah rumah tangga. Oleh karena itu, dalam usaha peningkatan pendapatan nelayan harus berorientasi pada masalah esensial nelayan, yakni kepemilikan faktor produksi dan sumberdaya modal.

Kusnadi, (2013) mengungkapkan, faktor yang selama ini dianggap berdampak pada kemiskinan nelayan adalah kondisi kekurangan sumberdaya produksi (alat tangkap). Faktor kepemilikan alat tangkap sangat penting dalam peningkatan produktifitas yang berdampak pada peningkatan penghasilan. Namun demikian, produktifitas tidak selalu relevan dengan kondisi kemiskinan nelayan. Substansi permasalahannya bukan semata pada produktifitas, namun justeru pada lemahnya posisi tawar (bargaining position) nelayan atas produktifitas yang dihasilkan akibat ketimpangan kepemilikan sumber daya produksi. Pada dasarnya dinamika aktivitas ekonomi nelayan ditentukan oleh dua aktor ekonomi, yakni nelayan sebagai produsen hasil tangkapan dan nelayan pemilik yang memasarkan hasil tangkapan nelayan.

Keberadaan nelayan pemilik dalam konteks masyarakat nelayan di Kelurahan Tidore telah menjadi pranata ekonomi lokal nelayan yang tidak hanya beroperasi dalam domain relasi-relasi ekonomi namun berlanjut dalam domain relasi sosial nelayan. Ketimpangan struktur kepemilikan modal dan alat tangkap merupakan faktor dominan yang menyebabkan nelayan membangun relasi dengan nelayan pemilik sebagai pemilik modal, ditambah biaya operasional melaut yang semakin tinggi, resiko ketidakmenentuan hasil tangkapan, pemenuhan kebutuhan harian dan berbagai tekanan lainnya mendorong nelayan membangun relasi dengan para pemberi/pemilik modal (individu/lembaga) sebagai katup penyelamat sekaligus meminimalisir resiko ketidakmenentuan aktivitas ekonomi.
Meskipun nelayan pemilik sebagai pranata ekonomi lokal memberikan berbagai bantuan terhadap nelayan, namun tidak dapat dikesampingkan bahwa relasi ekonomi dan sosial yang dijalankan tersebut dibangun didalam struktur ekonomi dan sosial yang identik dengan ketimpangan kepemilikan sumberdaya modal dan akses terhadap pasar, sehingga akan berdampak pada kemungkinan potensi keuntungan yang hanya dapat dinikmati oleh pemilik modal. Tentu saja kondisi tersebut akan mengakibatkan nelayan mencari sumbersumber lain untuk mencukupi kebutuhannya, yang berdampak timbulnya ketergantungan nelayan terhadap para pemberi/pemilik modal. Dalam kondisi ini, sangat sulit bagi nelayan untuk meningkatkan kesejahteraan.

Berkaitan dengan hal tersebut, keberadaan program BLM-PUMP di Kelurahan Tidore juga telah berdampak mengurangi ketergantungan nelayan terhadap para pemberi/pemilik modal seperti yang diuraikan diatas.

Keberadaan program BLM-PUMP di Kelurahan Tidore yang kurang efektif dikhawatirkan akan memberi dampak yang tidak baik, jika tidak ada penanganan yang serius terutama terhadap kelembagaan KUB yang tidak efektif. Kurangnya bimbingan dari pemerintah pasca penyaluran dana, mengakibatkan pengelola KUB tidak dapat mengelola dana secara optimal. Banyak nelayan yang memandang dana ini merupakan bantuan yang tidak perlu dikembalikan. Padahal maksud program ini yaitu KUB harus mampu mengelola dana dengan sebaik-baiknya.

Akibat dari kondisi tersebut, nelayan tidak lagi mempunyai sumber modal usaha, dikarenakan tidak ada perputaran modal. Realitas pemanfaatan BLMPUMP menunjukkan kecenderungan kegagalan pemanfaatan BLM-PUMP secara kelembagaan. Mayoritas KUB gagal menghidupkan aktivitas organisasi KUB. Padahal program BLM-PUMP menghendaki nelayan mampu berorganisasi secara mandiri guna memecahkan berbagai masalah dan mengembangkan potensi bersama. Alih-alih menghidupkan KUB sebagai pranata ekonomi nelayan, kegiatan KUB justru nyaris tidak berjalan pasca bantuan diberikan. Jika hal tersebut dibiarkan tanpa ada penanganan serius dari berbagai 
pihak yang terkait, dikhawatirkan nelayan akan kembali bergantung kepada para pelaku pemberi/pemilik modal yang jelas-jelas tidak memberikan keuntungan kepada nelayan tangkap dan nelayan buruh.

\section{KESIMPULAN DAN SARAN}

\section{Kesimpulan}

Berdasarkan hasil penelitian dan pembahsan yang telah diuraikan pada bab sebelumnya, maka diambil kesimpulan sebagai berikut :

1. Program Bantuan Langsung Masyarakat Pengembangan Usaha Mina Pedesaan (BLMPUMP) di Kelurahan Tidore telah sesuai dengan prosedur dan kriteria yang ditetapkan pemerintah. Ada beberapa kekurangan yang ditemukan dalam pelaksanaan program, antara lain : a) bantuan program bentuk non fisik tidak dipergunakan dengan optimal, antara lain sosialisasi program dan pelatihan tidak diikuti oleh seluruh pengelola KUB, manajemen pengurus KUB tidak berfungsi, dan kegiatan pengelolaan dana tidak mengikuti RUB; b) tidak ada perputaran modal; c) tenaga pembimbing tidak berfungsi dengan baik, kegiatan pendampingan dan pelatihan tidak dilanjutkan terus ke pasca penyaluran dana, terutama mengenai pembekalan pengetahuan pengelola KUB dalam mengelola dana. Program BLM-PUMP ini telah menghasilkan keluaran berupa infrastruktur penangkapan ikan yang masih digunakan sebagai aset bersama/KUB, dan Kelompok Usaha Bersama yang diharapkan berfungsi sebagai lembaga ekonomi masyarakat nelayan tidak berjalan dengan baik

2. Program BLM-PUMP di Kelurahan Tidore kurang berjalan efektif, karena tujuan program tidak tercapai sepenuhnya. Penyaluran dana BLMPUMP hanya mampu meningkatkan pendapatan nelayan dan cukup menumbuhkembangkan kewirausahaan nelayan, namun tidak mampu meningkatkan fungsi kelembagan KUB sebagai mitra lembaga keuangan bagi nelayan.

3. Program BLM-PUMP di Kelurahan Tidore memberikan dampak terhadap perekonomian masyarakat nelayan, yaitu meningkatkan pendapatan nelayan dan cukup mengurangi ketergantungan nelayan terhadap para pemberi/pemilik modal. (individu / lembaga).

\section{Saran}

1. Perlu segera diambil tindakan untuk menggerakkan kembali fungsi kelembagaan KUB, sehingga disarankan pengelola KUB segera melaporkan kondisi tersebut kepada instansi yang terkait.

2. Perlu diambil upaya lanjutan seperti monitoring dan evaluasi terhadap pelaksanaan program BLM-PUMP di Kelurahan Tidore oleh instansi yang terkait, karena sejak penyaluran dana sampai penelitian dilakukan belum dilakukan kegiatan monitoring dan evaluasi.

3. Intensitas kegiatan pembimbingan dari pemerintah perlu ditingkatkan dan menyediakan SDM tim pembimbing yang berkompeten.

4. Perlu ditingkatkan lagi kegiatan-kegiatan yang menunjang kualitas SDM nelayan, seperti pelatihan atau kursus.

\section{DAFTAR PUSTAKA}

Anonimous, 2011. Pembangunan Ekonomi Masyarakat Desa.

http://dinamikapembangunan.blogspot.com/201 1/05/pembangunan-ekonomi-masyarakatdesa.html. Diunggah pada tanggal 29 Agustus 2015.

Anonimous, 2012. Pedoman Umum KUB Perikanan Tangkap.

http://kubaceh.blogspot.com/2012/02/pedomanumum-kub-perikanan-tangkap.html. Diunggah pada tanggal 3 September 2015

Anonimous, 2013. Kewirausahaan. http://sandiasagede.blogspot.com/2013/03/kewi rausahaan.html. Diungah pada tanggal 3 September 2015

Arikunto, Suharsini. 2004. Prosedur Penelitian: Suatu Pendekatan Praktek. Rineka Cipta. Bandung. 
Dahuri, 2001. Pengelolaan Sumberdaya Wilayah Pesisir Secara Terpadu. Penerbit Pradnya Paramita. Jakarta.

Dinas Kelautan dan Perikanan. 2013. Pengembangan Usaha Mina Perdesaan Pemerintah Kabupaten Sangihe.

Direktorat Jendral Perikanan Tangkap Kementerian Kelautan dan Perikanan. 2012. Pedoman Teknis Pelaksanaan Kegiatan Pengembangan Usaha Mina Perdesaan Bidang Perikanan Tangkap Tahun 2012.J akarta

Edi Suharto, E. 2005. Kajian Strategis Pembangunan Kesejahteraan Sosial \&Pekerjaan Sosial. PT. Refika Aditama. Bandung

Handayaningrat, Soewarno. (1994). Pengantar Studi Ilmu Administrasi dan Manajemen. CV.Haji Masagung. Jakarta .

Hikmat A, 2006, Strategi Pemberdayaan Masyarakat. Humaniora Utama Press. 240 hlm, Bandung.

Hendro, Ir. 2011. Dasar-dasar Kewiraushaan. Erlangga. Jakarta.

Kusnadi. 2002. Konflik Sosial Nelayan Kemiskinan dan Perebutan Sumber Daya Alam. PT LKIS Pelangi Aksara .Yogyakarta

Kusnadi. 2003. Akar Kemiskinan Nelayan. Yogyakarta: LKis Pelangi Aksara. 136 hlm, Yogyakarta.

. 2009. Keberdayaan Nelayan dan Dinamika Ekonomi Pesisir. Pusat Penelitian Wilayah Pesisir dan Pulau-Pulau Kecil. Lembaga Penelitian Universitas, Jember.
Lambing Peggy Charles R. Kuehl. 2000. Entrepreneurship. New Jersey, Prentice Hall Inc

Mangkunegara, Anwar Prabu. (2006). Efaluasi Kinerja Sumber Daya Manusia. PT. Repika Aditama. Bandung

Rahim dan Astuti, 2007. Prinsip Dasar Ekonomi Pertanian. PT. RajaGrafindo Persada. Jakarta.

Saiman, Leonardus. 2009. Kewirausahaan: Teori, Praktik, dan kasus-kasus. Salemba Empat. Jakarta: Salemba Empat.

Sukirno, S., 2000. Makroekonomi Modern. PT.Raja Grafindo Persada. Jakarta.

Suparta, I Nyoman dan Ramantha, I Wayan. 2010. Manajemen Bisnis Kecil dan Kewirausahaan. Pustaka Nayottama. Denpasar.

Suryana,.2001. Kewirausahaan. Salemba Empat Jakarta.

2003. Kewirausahaan : Pedoman Praktis, Kiat, dan Proses Menuju Sukses. Edisi Revisi. Penerbit PT Salemba Empat Patria. Jakarta.

Suherman, Eman, 2008. Business Entrepreneur: Modal, Model, kewirausahaan. Alfabeta. Bandung.

Sugiarto, E., 2007. Teori Kesejahteraan Sosial Ekonomi dan Pengukurannya. Jurnal Eksekutif. Volume 4 Nomor 2. 